Reprod. Nutr. Dévelop., 1988, 28 (4 B), $1081-1091$

\title{
Plasma levels of progesterone in the domestic hen related to the maturation of ovarian follicles, and changes in the secretion of progesterone by granulosa cells cultured for 24 hours ( $\left.{ }^{\circ}\right)$
}

\author{
J. WILLIAMS
}

Station de Recherches Avicoles, I.N.R.A., Nouzilly, 37380 Monnaie, France.

Summary. Hens in their sixth month of lay were injected with a series of doses of ovine $\mathrm{LH}$, either following the oviposition of a mid-sequence egg (which is closely associated with an ovulation), or following the oviposition of the last egg of a sequence. The concentrations of steroid hormones were subsequently measured by radioimmunoassay in blood withdrawn at intervals after injection. No changes were observed in the concentrations of either testosterone or $17 \beta$-oestradiol, irrespective of the dose of $\mathrm{LH}$ or the stage of the ovulatory cycle. An increase in 4 -4-androstenedione was observed in all cases. This increase was minimal and unrelated to the dose of $\mathrm{LH}$ at the mid-sequence stage, but a dose-reponse relationship was observed in hens injected following the terminal oviposition of a series. Consistent, dose-related changes in the concentrations of progesterone in plasma were found at both stages of the ovulatory cycle, and the magnitude of these changes was 3.5-5 times greater than those observed for androstenedione.

Granulosa cells from the first, second and third ovarian follicles were dispersed by collagenase and stimulated with ovine LH either immediately or following a $24 \mathrm{~h}$ pre-incubation in medium 199. The amount of progesterone released into the medium after $3 \mathrm{~h}$ was assessed by radioimmunoassay. A progressive decrease in this response was observed in cells derived from the first to the third follicles in all cases. Cells challenged after $24 \mathrm{~h}$ always showed increased responses; cells from the second follicle secreted similar amounts of progesterone as cells from the first follicle that were challenged immediately, without pre-incubation. The responses obtained after $24 \mathrm{~h}$ were attenuated if no bovine serum albumin was present in the medium, or if ovine $\mathrm{LH}$ had been present in the medium continuously.

These results are interpreted as evidence for an increase in the secretion of progesterone by the granulosa cells of the hen which is linked to the maturation of the follicle. The final stages of this maturation may proceed in the absence of $\mathrm{LH}$.

\section{Introduction.}

Ovulation occurs at approximately daily intervals in the domestic hen and eggs are laid in sequences which vary in length. The interval between the last ovulation of one sequence and the first ovulation of the next is approximately

() These results were partially presented at the 176th meeting of the Society for Endocrinology, London, U.K. 
$42 \mathrm{~h}$. This is around $16 \mathrm{~h}$ longer than the time elapsing between subsequent ovulations within a sequence. It is important to understand why this delay occurs from a practical point of view as it is an important factor limiting the rate of lay of certain strains of hen.

It is now well accepted that ovulation in the hen is preceded by pre-ovulatory surges of luteinizing hormone (LH) and the steroid hormones progesterone, testosterone, androstenedione (Laguë et al., 1975; Etches and Cunningham, 1977 ; Etches, 1984), and that progesterone exerts a positive feedback on the mechanisms controlling the release of LH (Wilson and Sharp, 1975 ; Etches and Cunningham, 1976). Thus, the failure of the first ovulation of a sequence to occur sooner may be due to an inability of the pituitary to secrete sufficient LH, of the ovarian follicle to respond by ovulating and/or secreting progesterone or other steroid hormones, or a failure of structures in the central nervous system to respond to increased steroid secretion. Pituitary incompetence or the inability of a follicle to ovulate are unlikely as it is possible to add extra eggs to a sequence by injecting either progesterone or anterior pituitary extract (Neher and Fraps, 1950) or $\mathrm{LH}-\mathrm{RH}$ (Etches et al., 1983). Furthermore, it is possible to induce a premature ovulation with a $50 \%$ chance of success by injecting $20 \mu \mathrm{g} \mathrm{LH}-\mathrm{RH}$ within 13-15 h of a preceding mid-sequence or terminal ovulation (Etches et al., 1983). These authors also showed that the progesterone secretion response of the ovary to a graded series of ovine $\mathrm{LH}(\mathrm{oLH})$ injections was greater in animals challenged approximately $5 \mathrm{~h}$ after the terminal oviposition (which is separated from the succeeding ovulation $16 \mathrm{~h}$ later) than in animals injected $5 \mathrm{~h}$ after a mid-sequence oviposition (which is closely followed by an ovulation). The difference in these responses may be due to the state of maturation of the granulosa cells of the largest ovarian follicle which are the major source of circulating progesterone in the hen (Etches et al., 1981).

The object of the present experiment was to verify the steroid secretion response of the ovary according to the state of maturation of the largest follicle and to assess the changes in the progesterone secretion response of isolated granulosa cells either immediately following isolation or after a $24 \mathrm{~h}$ period of culture. This was intended to simulate the final stages of maturation which the cells would have undergone within the ovary, thus it was hoped to partially determine the correct conditions for the maturation of granulosa cells.

\section{Materials and methods.}

Animals and husbandry. - I.S.A. Brown hens (I.S.A., Châteaubourg, France) in their sixth (experiment 1) or ninth (experiment 2) month of lay were selected for these experiments on the basis of regular egg-laying sequences. They were maintained in individual cages equipped with automatic oviposition recording time devices and given feed and water ad libitum. The experimental room was maintained at a temperature of $19{ }^{\circ} \mathrm{C} \pm 1{ }^{\circ} \mathrm{C}$, and the relative humidity was $65 \pm 5 \%$. The exterior sound attenuation was $-70 \mathrm{~dB}$ and a photoperiod of $14 \mathrm{~h}$ light and $10 \mathrm{~h}$ of darkness was used. 


\section{Experimental protocols.}

1) The stage of the ovulatory cycle (i.e. mid-sequence or end of sequence) was determined by the hens' history of lay and by the time of lay of eggs within a sequence (Heywang, 1938). Ovulation of a mid-sequence egg was considered to occur within 15-45 min of oviposition (Warren and Scott, 1935). Groups of hens ( $n=6$ minimum; $n=8$ maximum) were injected intravenously from $5-9 h$ following a mid-sequence oviposition/ovulation (referred to below as the $\mathrm{O}_{\mathrm{n}}$ stage), or within $5-9 \mathrm{~h}$ of a terminal oviposition (referred to below as the $\mathrm{O}_{\mathrm{t}}$ stage) with either: $0.9 \%$ saline (controls); 10,20 or $50 \mu \mathrm{g}$ oLH (S-16, NIDDK, Bethesda, U.S.A.) per kg live weight. Five $\mathrm{ml}$ of blood were withdrawn by brachial venepuncture into a heparinized syringe at $0,30,60,90$ and $120 \mathrm{~min}$ following injection. Plasmas were separated by centrifugation and stored at $-20^{\circ} \mathrm{C}$ until required for assays of steroid hormones.

2) Six hens were sacrificed within 3-4 h of laying a mid-sequence egg on day 0 . The three largest ovarian follicles (hereinafter designated F1, F2 and F3 respectively) were quickly removed, weighed and placed in ice-cold $0.9 \%$ saline solution. Granulosa cells were separated as described by Williams and Johnson (1987). Incubations were performed in MicroTest II tissue culture plates (Falcon, Oxnard, CA, U.S.A.) using 25,000 cells in $250 \mu$ l of M199 (Serva, Heidelberg, Germany) containing (unless otherwise stated) $0.1 \%$ bovine serum albumin (BSA ; Fraction V, Sigma, St. Louis, MO, U.S.A.), $5.6 \mathrm{mM}$ glucose (Aldrich Gold Mark, Steinheim, W. Germany) and 10 mM HEPES (Sigma). Three experimental protocols were employed:

a. Four replicate wells were assigned to the following treatments on day 0 : $0.1 \%$ BSA, oLH $100 \mathrm{ng} / \mathrm{ml}$; no BSA, oLH $100 \mathrm{ng} / \mathrm{ml} ; 0.1 \%$ BSA, no oLH ; no BSA, no oLH. Cells were incubated for $3 \mathrm{~h}$ at $37^{\circ} \mathrm{C}$ under $5 \% \mathrm{CO}_{2}$. The supernatants were removed and stored at $-20^{\circ} \mathrm{C}$ until required for assay.

b. The cells were first incubated in M199 containing 100,000 I.U. penicillin (Flow laboratories, Asnières, France) and $100 \mathrm{mg} / \mathrm{ml}$ streptomycin (Flow laboratories, Asnières, France) for $24 \mathrm{~h}$ (day 0 to day 1 ). This medium was changed on day 1 and four replicate wells were assigned to the same treatments as protocol a above and incubated for a further $3 \mathrm{~h}$. Supernatants were then removed and frozen at $-20^{\circ} \mathrm{C}$.

c. As b except that $100 \mathrm{ng} / \mathrm{ml}$ oLH was added to the medium used for the first $24 \mathrm{~h}$ of culture.

The milieu were assayed to determine progesterone concentrations.

Assay procedures. - Progesterone was assayed according to the procedure described by Duplaix, Williams and Mongin (1981), androstenedione according to that of Williams and de Reviers (1981), testosterone according to that of Driot, de Reviers and Williams (1979) and oestradiol according to that of Etches, Williams and Rzasa (1984). The imprecision profiles of the assays needed to assay the present samples did not differ significantly from the mean profiles (calculated from assay history) of each assay.

Calculations and statistical analyses. - Radioimmunoassay data were reduced using the NIHRIA program (Rodbard, Huston and Munson, 1980). 
The increases in steroid concentrations in plasma were always maximal at $30 \mathrm{~min}$ after injection of oLH, therefore the change in concentration for each hormone and each animal was calculated by subtracting the pre-injection value from the $30 \mathrm{~min}$ post-injection value.

The concentrations of progesterone secreted in vitro are expressed as $\mathrm{ng} / 10^{5}$ cells $/ 3 \mathrm{~h}$ to facilitate comparison with other published work.

Analyses of variance were performed using an appropriate linear model in the MGLH module of the Systat program (Systat, Evanston, III., U.S.A.). Post hoc comparisons were made using Turkey's HSD test at the $5 \%$ probability level unless otherwise stated.

\section{Results.}

\section{Experiment 1.}

$O_{n}$ stage (fig. 1, 3 and 4). - There were no changes in the plasma concentrations of any of the steroid hormones assayed in the hens that were injected with saline. Injecting oLH at any dose did not result in perceptible increases in either oestradiol or testosterone, whereas a change of approximately $0.5 \mathrm{ng}$ androstenedione per $\mathrm{ml}$ plasma was observed at all doses administered. Changes in the plasma concentrations of progesterone were observed which were proportional to the dose of oLH and ranged from approximately 1.2 $(10 \mu \mathrm{g} / \mathrm{kg}$ dose) to approximately $3.5 \mathrm{ng} / \mathrm{ml}(50 \mu \mathrm{g} / \mathrm{kg}$ dose).

$O_{t}$ stage (fig. 2, 3 and 4). - There were no changes in the plasma concentrations of any of the steroid hormones assayed in the hens that were injected with saline. Injecting oLH at any dose did not result in perceptible increases in either oestradiol or testosterone, whereas a change of approximately $0.8 \mathrm{ng}$ androstenedione per $\mathrm{ml}$ plasma was observed at the dose of $10 \mu \mathrm{g} / \mathrm{kg}$ rising to a change of approximately $1.3 \mathrm{ng}$ per $\mathrm{ml}$ plasma at the dose of $50 \mu \mathrm{g} / \mathrm{kg}$. Clear increases were observed in progesterone plasma concentrations which ranged from approximately $2.6 \mathrm{ng} / \mathrm{ml}(10 \mu \mathrm{g} / \mathrm{kg}$ dose $)$ to approximately $5.8 \mathrm{ng} / \mathrm{ml}$ (50 $\mu \mathrm{g} / \mathrm{kg}$ dose).

Figures 1 and 2 emphasize the relatively greater changes in progesterone compared to androstenedione, testosterone and oestradiol. Error bars have been omitted for the sake of clarity. The results are shown regrouped, for androstenedione at each stage in figure 3 , and for progesterone in figure 4 to highlight the differing secretory responses at each stage of the ovulatory cycle.

\section{Experiment 2}

These results are shown in figure 5 . The mean secretion of progesterone by F1 granulosa cells irrespective of the experimental treatments ( $38.6 \mathrm{ng} / 10^{5}$ cells $/ 3 \mathrm{~h}$ ) was always greater than the mean secretion by $\mathrm{F} 2$ granulosa cells $\left(18.6 \mathrm{ng} / 10^{5}\right.$ cells $\left./ 3 \mathrm{~h}\right)$ which, in turn, secreted more progeste- 


\section{On Oviposition}

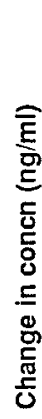

$\left.\begin{array}{l}6 \\ 4 \\ \\ 2 \\ \end{array}\right]$

a

I

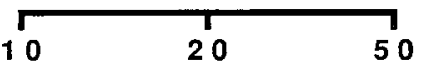

Micrograms oLH/Kg body weight

Ot Oviposition

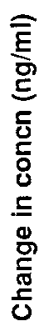

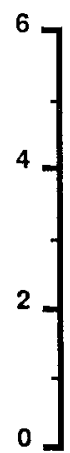

g
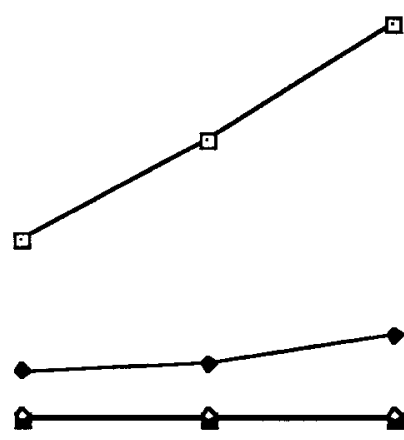

-1- Progesterone

- Androstenedione

$\rightarrow$ Oestradiol

$\sim$ Testosterone

I

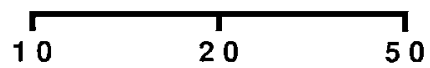

Micrograms oLH/Kg body weight

FIG. 1. (UPPER PANEL) - Mean changes in the plasma concentrations of progesterone, androstenedione, oestradiol and testosterone in groups of hens injected within 5-9 h of a mid-sequence oviposition with either $O(n=5), 10(n=6), 20(n=7)$ or $50(n=6) \mu g$ ovine $L H / k g$ body weight in $0.9 \%$ saline.

FIG. 2. (LOWER PANEL) - Mean changes in the plasma concentrations of progesterone, androstenedione, oestradio/ and testosterone in groups of hens injected within 5-9 h of a terminal oviposition with either $O(n=4), 10(n=8), 20(n=6)$ or $50(n=6) \mu g$ ovine $L H / k g$ body weight in $0.9 \%$ saline. 

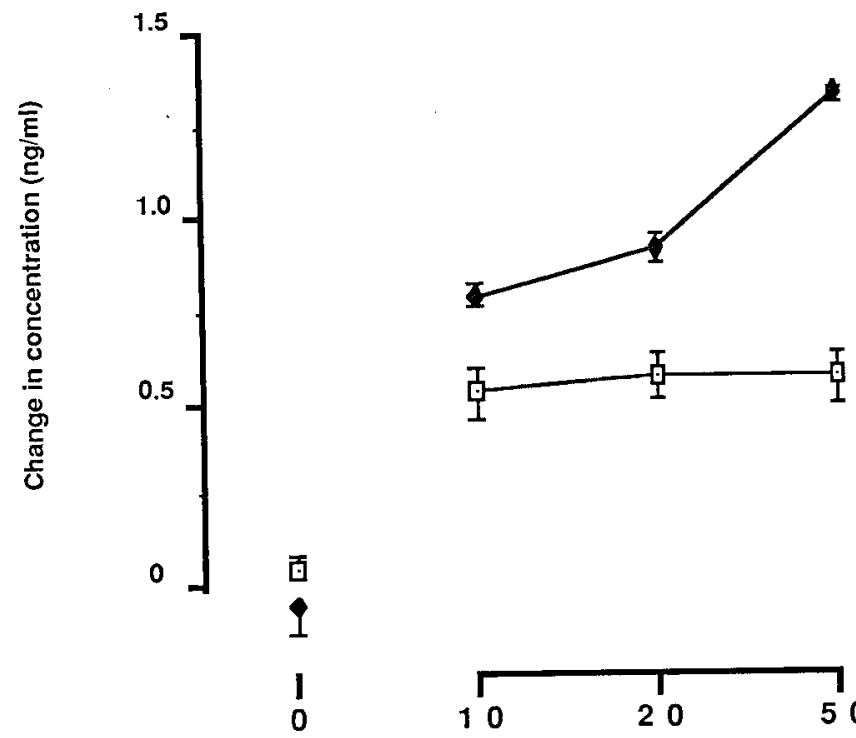

$\rightarrow$ Androstenedione On

$\rightarrow$ Androstenedione Ot

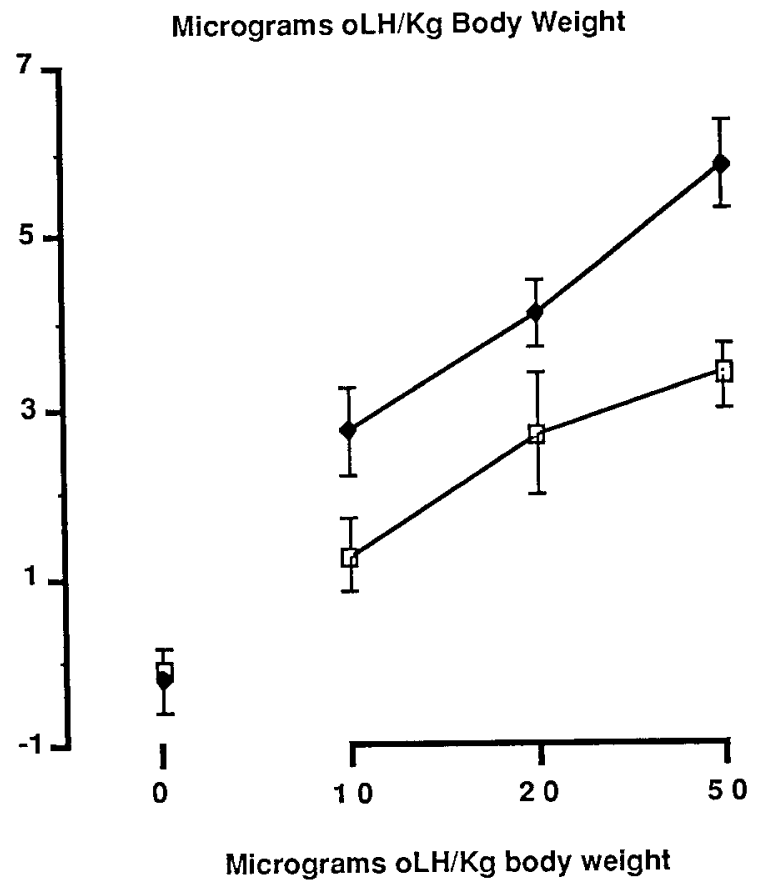

$\rightarrow$ Progesterone On

$\uparrow$ Progesterone Ot

FIG. 3. (UPPER PANEL) - Mean changes in the plasma concentrations of androstenedione in groups of hens injected within 5-9h of either a mid-sequence oviposition $\left(\mathrm{O}_{n}\right)$ or a terminal oviposition $\left(\mathrm{O}_{\mathrm{t}}\right)$ with either $0,10,20$ or $50 \mu \mathrm{g}$ ovine $\mathrm{LH} / \mathrm{kg}$ body weight. The numbers of hens are given in the legends to figures $1 \& 2$.

FIG. 4. (LOWER PANEL) - Mean changes in the plasma concentrations of progesterone in groups of hens injected within $5-9$ h of either a mid-sequence oviposition $\left(\mathrm{O}_{n}\right)$ or a terminal oviposition $\left(\mathrm{O}_{\mathrm{t}}\right)$ with either $0,10,20$ or $50 \mathrm{\mu g}$ ovine $\mathrm{LH} / \mathrm{kg}$ body weight. The numbers of hens are given in the legends to figures $1 \& 2$. 


\section{Basal and oLH stimulated Progesterone Secretion by Hen Granulosa Cells cultured with or without $0.1 \%$ BSA}

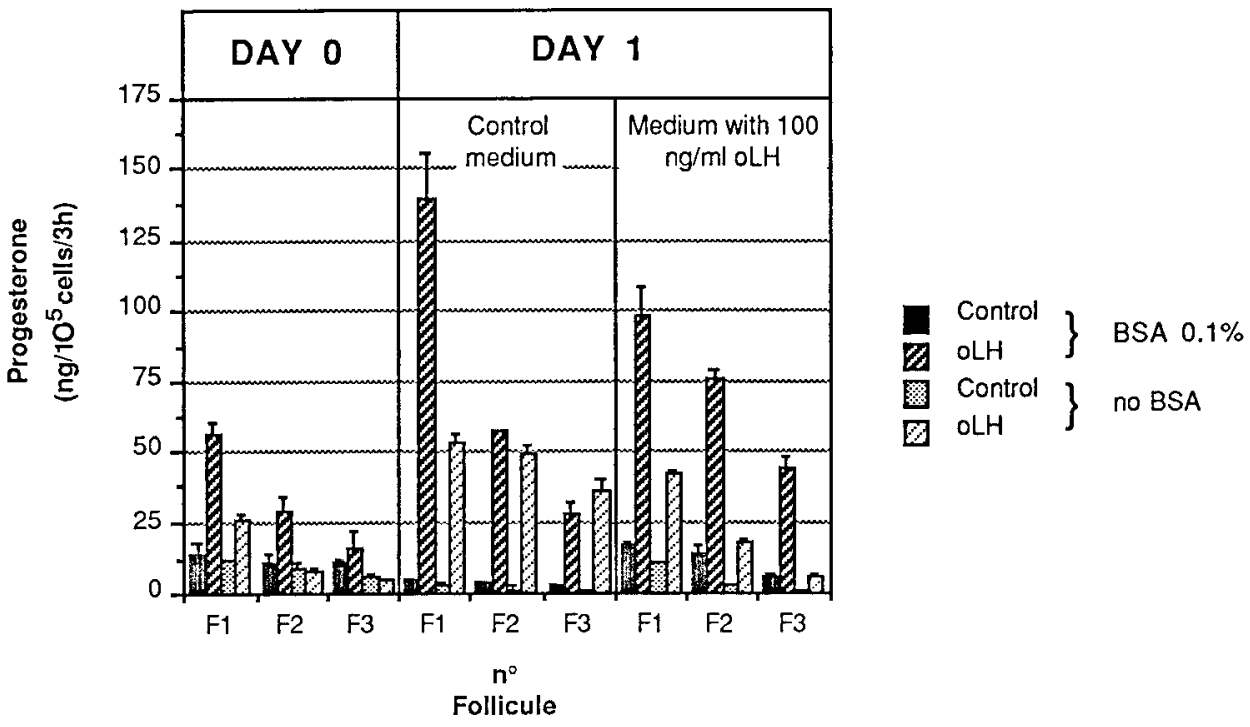

FIG. 5. - Progesterone (ng hormone/100,000 cells/3 h) secreted in vitro in M199 medium by chicken granulosa cells of the first (F1), second (F2) or third (F3) largest ovarian follicles obtained from six hens. Measurements were either made on the day of removal of the follicles (Day 0), or following a 24 hour preincubation period (Day 1 ).

Key to legend : oLH - $100 \mathrm{ng} / \mathrm{ml}$ ovine LH ; control- medium 199 alone ; BSA $0.1 \%$ - medium containing $0.1 \%$ bovine serum albumin ; no BSA - medium without bovine serum albumin.

rone than F3 granulosa cells $\left(12.9 \mathrm{ng} / 10^{5}\right.$ cells $\left./ 3 \mathrm{~h}\right)$. The mean concentration of progesterone in the medium of cells stimulated with LH for $3 \mathrm{~h}$ was significantly greater $(P=0.0001)$ than that in the medium of unstimulated cells (mean concentrations $41.8 \mathrm{vs} .6 .4 \mathrm{ng} / 10^{5}$ cells $/ 3 \mathrm{~h}$ respectively). Cells incubated in the presence of BSA secreted significantly greater $(P=0.0001)$ quantities of progesterone (mean $=29.8$ ) than cells incubated in the absence of BSA (mean $=17.3 \mathrm{ng} / 10^{5}$ cells $/ 3 \mathrm{~h}$ ).

The mean level of progesterone secreted on day 1 by cells incubated for $24 \mathrm{~h}$ in medium without oLH $\left(30.4 \mathrm{ng} / 10^{5}\right.$ cells $\left./ 3 \mathrm{~h}\right)$ was significantly $(\mathrm{P}=0.02)$ different from the mean level secreted by cells on day $0\left(16.7 \mathrm{ng} / 10^{5}\right.$ cells $\left./ 3 \mathrm{~h}\right)$.

There was no significant difference in the mean level of progesterone secreted on day 1 by cells incubated with oLH for $24 \mathrm{~h}\left(27.8 \mathrm{ng} / 10^{5}\right.$ cells $\left./ 3 \mathrm{~h}\right)$ and that of cells incubated without oLH for $24 \mathrm{~h}\left(30.4 \mathrm{ng} / 10^{5} \mathrm{cells} / 3 \mathrm{~h}\right)$. Cells pre-incubated in either medium responded to the $\mathrm{OLH}$ challenge but the mean increase (calculated as : mean level oLH treatment - mean level unstimulated controls) in progesterone secretion was significantly $(P=0.046)$ greater for cells 
which had not been pre-incubated with oLH ( $+58.3 \mathrm{ng} / 10^{5}$ cells $/ 3 \mathrm{~h}$ ) than for cells which had been pre-incubated with oLH $\left(+39.0 \mathrm{ng} / 10^{5}\right.$ cells $\left./ 3 \mathrm{~h}\right)$.

\section{Discussion.}

The failure to stimulate any increase in oestradiol secretion in hens injected with oLH is at variance with the results of Etches (1984) who demonstrated an increase from 100 to $200 \mathrm{pg} / \mathrm{ml}$ in plasma levels followed a $25 \mu \mathrm{g}$ injection of $\mathrm{LH}-\mathrm{RH}$ which also induced an $\mathrm{LH}$ surge and premature ovulation. However, this occurred $3 \mathrm{~h}$ after injection whereas peak values were observed in the present experiment 30 minutes after oLH injection. Also, Laguë et al. (1975) found that preovulatory LH peaks were not always accompanied by oestradiol peaks, while Johnson and van Tienhoven (1980) commented on the variability of peak oestradiol levels during the hen's ovulatory cycle. A possible explanation for these discrepancies is the different assay techniques used by each author and the difficulties in assaying this hormone in laying hen plasma. It is, however, clear that oestradiol cannot induce premature ovulation or LH release in the hen (Wilson and Sharp, 1976a) or LH release in the ovariectomized hen (Wilson and Sharp, 1976b).

Etches (1984) reported larger increases in plasma testosterone levels than those found here but, as in the case of this author's oestradiol data, the peak values occurred later than in this experiment. The levels reported here are in general agreement with other reports (Etches and Cunningham, 1977 ; Johnson and van Tienhoven, 1980).

The changes in androstenedione and progesterone found were greater than those observed for oestradiol and testosterone. It is also clear that the changes in plasma progesterone are greater than the change in plasma androstenedione at both $\mathrm{O}_{n}$ and $\mathrm{O}_{\mathrm{t}}$ stages, and at all dose levels of oLH. This is in agreement with Etches and Duke (1984) who found that the granulosa cell content of progesterone was generally greater than that of androstenedione. Furthermore, these changes were larger at the $O_{t}$ stage than at the $O_{n}$ stage. This indicates that changes in the maturational state of the largest follicle, expressed in terms of steroid secretion, occur during the $24 \mathrm{~h}$ which precede ovulation.

Huang et al. (1979) conducted a series of studies on the synthesis of steroids by chicken theca and granulosa cells and suggested that progesterone synthesized by the granulosa cells may pass to thecal cells where it is converted to androgens and oestrogens. Since they found only low levels of testosterone compared to progesterone secreted by granulosa cells, they did not suggest that androgens secreted by the granulosa cell might serve as substrates for oestrogen synthesis by the theca cells. The present results for progesterone and testosterone confirm these earlier observations, but the higher levels of androstenedione compared to testosterone secreted by maturing granulosa cells raise the question whether androstenedione may be metabolized to oestrogens by the theca cells. Further metabolism to oestrogens in the granulosa cell is unlikely in view of the very low levels of oestradiol-17 $\beta$ secretion reported here. 
The progesterone measured in these experiments is probably the result of synthesis of the compound rather than release of intracellular stores into the incubation medium as no difference has been observed between the quantities of progesterone measured in the medium alone and in the medium with homogenized cells (personal observations; Huang and Nalbandov, 1979). Also, the capacity of chicken granulosa cells to synthesize progesterone from $\left[6-{ }^{3} \mathrm{H}\right]$ 25-hydroxycholesterol has been demonstrated by Scarlata, Mikhail and Hertelendy (1984).

The in vitro experiments confirmed the hierarchy of secretion of progesterone by the granulosa cells of the first, second and third follicles which has been reported previously by Etches and Duke (1984) and Bahr et al. (1983). It is interesting to note that when cells are incubated for a period of $24 \mathrm{~h}$ (which approximates to the period between successive ovulations), their progesterone secreting response to $\mathrm{LH}$ increases indicating that the final stages of maturation can proceed under the in vitro conditions employed here. Interestingly, cells from either the F1, F2 or the F3 follicles displayed the same tendency to increase their progesterone secreting capability.

However, the correct conditions for the maturation of the progesterone secreting response of the granulosa cells remain to be defined. It is possible that BSA, or a factor present in the BSA used here, is necessary as the responses were either greater when BSA was present in the medium, or failed to develop when BSA was absent. This effect was seen clearly when the cells were pre-incubated in a medium containing oLH, but is was less evident if oLH was absent from the pre-incubation medium (except for the F1 follicle). While LH may be thought of as a necessary adjunct to an incubation medium since the cells are normally exposed to it in the in vivo environment, there was a tendency towards overdevelopment of the progesterone secretion response; the F2 follicle responded more on day 1 than the $F 1$ follicle on day 0 , and the F3 on day 1 responded more than the F2 on day 0 . Such overdevelopment did not seem to take place if $\mathrm{LH}$ was not present during preincubation. The development of serum-free media and the recognition of the importance of insulin or insulin-like factors (such as (GF-1), transferrin and fibronectin in the determination of the optimum conditions for cell growth and differentiation suggest ways of defining the precise conditions for allowing avian granulosa cells to mature in vitro.

Recu en octobre 1987. Accepté en avril 1987. 8

Acknowledgements. - This work was supported by I.N.R.A. grant A.T.P. 4534 " Hormones hypophysaires et fonctions de reproduction chez les Vertébrés ». The NIDDK and the NHPP, University of Maryland School of Medicine kindly provided the ovine LH. The expert technical assistance of Mme M.-T. Durand and Mme M. Garreau-Mills is gratefully acknowledged. 
Résumé. Relations entre les niveaux plasmatiques de progestérone et la maturation des follicules ovariens chez la poule pondeuse, et l'évolution de la sécrétion de progestérone par les cellules de la granulosa mises en culture pendant $24 \mathrm{~h}$.

Dans une première expérience, différentes doses de LH ovine ont été injectées à des poules pondeuses dans leur $6^{\mathrm{e}}$ mois de ponte, soit après oviposition d'un œuf de milieu de série (c'est-à-dire en association temporelle étroite avec l'ovulation), soit après oviposition du dernier œuf d'une série.

Les concentrations plasmatiques en hormones stéroïdiennes (progestérone, androstènedione, testostérone et $17 \beta$-œstradiol) des échantillons collectés après injection sont mesurées par dosages radioimmunologiques. L'injection de LH, à l'un ou l'autre des deux stades du cycle ovulatoire choisis, $n^{\prime}$ induit aucune variation des concentrations de testostérone et de $17 \beta$-œstradiol, par contre une augmentation des concentrations d'androstènedione y est systématiquement associée. En milieu de série, cette augmentation est minimale et indépendante de la dose de LH injectée, alors qu'une relation dose-réponse est observée lorsque l'injection est pratiquée en fin de série. La relation dose-réponse attendue pour la progestérone est mise en évidence à chacun des stades du cycle ovulatoire. La magnitude de ces variations est 3,5 à 5 fois plus importante que celle mesurée pour l'androstènedione.

La seconde expérience consiste en l'incubation, en présence ou non de LH ovine ou de 8-bromo AMP cyclique, de cellules de la granulosa des $1^{\mathrm{e}}, 2^{\mathrm{e}}$ et $3^{\mathrm{e}}$ follicules ovariens, soit immédiatement, soit après une période de préincubation de $24 \mathrm{~h}$ dans du milieu M199. La quantité de progestérone sécrétée après $3 \mathrm{~h}$ d'incubation est mesurée par dosage radioimmunologique. La réponse est d'autant plus forte que le follicule dont sont issues les cellules occupe un rang élevé dans la hiérarchie. Elle est accrue après une période d'incubation de $24 \mathrm{~h}$; ainsi des cellules provenant des seconds follicules (F2) sécrètent alors une quantité de progestérone comparable à celle sécrétée par des cellules de premier follicule (F1) non soumises à une préincubation. A l'opposé, l'absence de BSA dans le milieu où la présence de $\mathrm{LH}$ en continu durant la période de préincubation atténue la réponse mesurée.

Ces résultats indiquent que l'augmentation de la sécrétion de progestérone par les cellules de granulosa est associée à la maturation folliculaire. Les phases terminales de ce processus peuvent être menées à bien en l'absence de LH.

\section{References}

BAHR J. M., WANG S.-C., HUANG M. Y., CALVO F. O., 1983. Steroid concentrations in isolated theca and granulosa layers of preovulatory follicles during the ovulatory cycle of the domestic hen. Biol. Reprod., 29, 326-344.

DRIOT F. J. M., de REVIERS M., WILLIAMS J., 1979. Plasma testosterone levels in intact and hemicastrated growing cockerels. J. Endocr., 81, 169-174.

DUPLAIX M., WILLIAMS J., MONGIN P., 1981. Effects of an intermittent lighting schedule on the time of egg-laying and the levels of luteinizing hormone, progesterone and corticosterone in the plasma of the domestic hen. J. Endocr., 91, 375-383.

ETCHES R. J., 1984. Maturation of ovarian follicles, 51-73. In F. J. CUNNINGHAM, P. E. LAKE \& D. HEWITT, Reproductive biology of poultry, Longmans Publ.

ETCHES R. J., CROZE F., DUKE C. E., 1981. Plasma concentrations of luteinizing hormone, progesterone, testosterone and oestradiol in follicular and venous plasma during the ovulation cycle of the hen in Recent advances in avian endocrinology. Adv. Physiol. Sci, 33, $89-98$.

ETCHES R. J., CUNNINGHAM F. J., 1976. The interrelationship between progesterone and luteinizing hormone during the ovulation cycle of the hen (Gallus domesticus). J. Endocr., 71, 51-58. 
ETCHES R. J., CUNNINGHAM F. J., 1977. The plasma concentrations of testosterone and LH during the ovulation cycle of the hen (Gallus domesticus). Acta endocrinol., 84, 357-366.

ETCHES R. J., DUKE C. E., 1984. Progesterone, androstenedione and oestradiol content of theca and granulosa tissues of the four largest ovarian follicles during the ovulatory cycle of the hen (Gallus domesticus). J. Endocr., 103, 71-76.

ETCHES R. J., MACGREgOR H. E., MORRIS T. F., WILLIAMS J. B., 1983. Follicular growth and maturation in the domestic hen (Gallus domesticus). J. Reprod. Fert., 67, 351-358.

ETCHES R. J., WILLIAMS J. B., RZASA J., 1984. Effects of corticosterone and dietary changes in the hen on ovarian function, plasma $\mathrm{LH}$ and steroids and the response to exogenous $\mathrm{LH}-\mathrm{RH}$ $J$. Reprod. Fert., 70, $121-130$.

HEYWANG B. W., 1938. The time factor in egg formation. Poult. Sci, 17, 240-247.

HUANG E. S.-R., KAO K. J., NALBANDOV A. V., 1979. Synthesis of sex steroids by cellular components of chicken follicles. Biol. Reprod., 20, 454-461.

JOHNSON A. L., van TIENHOVEN A., 1980. Plasma concentrations of six steroids and LH during the ovulatory cycle of the hen (Gallus domesticus). Biol. Reprod., 23, 386-396.

LAGUË P. C., van TIENHOVEN A., CUNNINGHAM F. J., 1975. Concentrations of estrogens, progesterone and $\mathrm{LH}$ during the ovulatory cycle of the laying chicken (Gallus domesticus). Biol. Reprod., 12, 590-598.

NEHER B. H., FRAPS R. M., 1950. The addition of eggs to the hen's clutch by repeated injection of ovulation-inducing hormones. Endocrinology, 46, 482-488.

RODBARD D., HUSTON Jr. J., MUNSON P. J., 1980. BASRIA (RIA data processing: BASIC programs). Biomedical Computing Technology Information Center, MED-39

SCARLATA C. S., MIKHAIL G., HERTELENDY F., 1984. Clomiphene and tamoxifen inhibit progesterone synthesis in granulosa cells : comparison with estradiol. Endocrinology, 114. 2032-2038.

WARREN D. C., SCOTT H. M., 1935. The time factor in egg formation. Poult. Sci., 14, 195-207.

WILLIAMS J., de REVIERS M., 1981. Variations in the plasma levels of luteinizing hormone and androstenedione and their relationship with the adult daily sperm output in cockerels raised under different photoschedules. Reprod. Nutr. Dév., 21, 1125-1135.

WILSON S. C., SHARP P. J., 1975. Changes in the plasma concentrations of luteinizing hormone after the injection of progesterone at various times during the ovulatory cycle of the domestic hen (Gallus domesticus). J. Endocr., 67, 59-70.

WILSON S. C., SHARP P. J., 1976a. Effects of androgens, oestrogens and deoxycorticosterone acetate on plasma concentrations of luteinizing hormone in laying hens. J. Endocr., 69, 93-102.

WILSON S. C., SHARP P. J., 1976b. Induction of luteinizing hormone release by gonadal steroids in the ovariectomized domestic hen. J. Endocr., 71, 87-98. 